\title{
TGM6 L517W is not a pathogenic variant for spinocerebellar ataxia type 35
}

Yanxing Chen, MD, PhD, Dengchang Wu, MD, PhD, Benyan Luo, MD, PhD, Guohua Zhao, MD, PhD, and Kang Wang, MD, PhD

Neurol Genet 2020;6:e424. doi:10.1212/NXG.0000000000000424

\author{
Correspondence \\ Dr. Zhao \\ gzhao@zju.edu.cn \\ or Dr. Wang \\ fcwangk1@zju.edu.cn
}

\begin{abstract}
Objective

To investigate the pathogenicity of the TGM6 variant for spinocerebellar ataxia 35 (SCA35), which was previously reported to be caused by pathogenic mutations in the gene TGM6.
\end{abstract}

\section{Methods}

Neurologic assessment and brain MRI were performed to provide detailed description of the phenotype. Whole-exome sequencing and dynamic mutation analysis were performed to identify the genotype.

\section{Results}

The proband, presenting with myoclonic epilepsy, cognitive decline, and ataxia, harbored both the TGM6 p.L517W variant and expanded CAG repeats in gene ATN1. Further analysis of the other living family members in this pedigree revealed that the CAG repeat number was expanded in all the patients and within normal range in all the unaffected family members. However, the TGM6 p.L517W variant was absent in 2 affected family members, but present in 3 healthy individuals.

\section{Conclusions}

The nonsegregation of the TGM6 variant with phenotype does not support this variant as the disease-causing gene in this pedigree, questioning the pathogenicity of TGM6 in SCA35. 


\section{Glossary}

AD = autosomal dominant; DRPLA = dentatorubral-pallidoluysian atrophy; GTCS = generalized tonic-clonic seizure; SCA = spinocerebellar ataxia.

Spinocerebellar ataxias (SCAs) are a group of autosomal dominant $(\mathrm{AD})$ disorders that mainly affect the cerebellar function. SCAs are genetically heterogeneous, and there are more than 40 subtypes of SCAs and more than 30 genes identified responsible for them (neuromuscular.wustl.edu/). SCA35 was reported to be associated with mutation in transglutaminase 6 gene (TGM6), which codes for transglutaminase 6 protein (TG6) in 2010. ${ }^{1}$ A 4-generation Chinese AD-SCA family was identified to have 9 affected members showing progressive gait instability, scanning speech, and poor dexterity in hands. Linkage analysis suggested that the disease-causing gene was located on chromosome 20p13-12.2, and exome sequencing showed that the c.1550T>G (p.L517W) variant cosegregated with the phenotypes. Another variant c.980A $>\mathrm{G}$ (D327G) was identified in another AD-SCA family. ${ }^{2}$ In the following years, another 13 variants were reported in different ethnic groups including Chinese, Asian, European, and Hispanic, ${ }^{2-9}$ mainly in Asia. Here, we report an $\mathrm{AD}$ family with 6 patients presenting with ataxia. Nonsegregation of the TGM6 p.L517W variant with phenotype questions the pathogenicity of this variant.

\section{Methods}

\section{Participants}

The 4-generation pedigree was recruited from the First Affiliated Hospital of Zhejiang University School of Medicine. Neurologic examination was performed by at least 2 senior neurologists.

\section{Standard protocol approvals, registrations, and patient consents}

This study was approved by the Medical Ethics Committee of the First Affiliated Hospital of Zhejiang University School of Medicine (No. 2017-326). Written informed consent was obtained from each participant or from a legal representative.

\section{Genetic analysis}

Genomic DNA was extracted from the peripheral blood of family members. Exon-enriched DNA sequencing and bioinformatic analysis were performed on the Illumina HiSeq X-ten (Illumina, CA) in high-output mode with 150 bp pairedend reads following the manufacturer's instructions (Illumina) in the proband. The suspected pathogenic variants were validated by Sanger sequencing. The results of Sanger sequencing performed in other living family members were used for cosegregation analysis. A dedicated panel for screening SCAs including SCA1, 2, 3, 6, 7, 8, 10, 12, 17, and dentatorubralpallidoluysian atrophy (DRPLA) was used to test repeat expansions of related mutations in all the available family members. Briefly, 22-FAM-labeled primer sets were used for triplet repeat primed PCR, followed by PCR product processed by capillary electrophoresis with the ABI3730xl (Applied Biosystems, Foster, CA). The primer sequences of all SCAs genes were designed using reference sequences from GenBank. Data were analyzed with GeneMapper v4.0 (Applied Biosystems).

\section{Data availability}

The data that support the findings of this study are available from the corresponding author on reasonable request.

\section{Results}

The proband (IV:1, figure, A) is a 28-year-old woman, who presented to the neurology outpatient clinic with a 13-year history of unprovoked seizures. She developed generalized tonic-clonic seizures (GTCSs) at age 15 years, which mainly occurred in the morning, on awakening. She was then prescribed with several antiepileptic drugs, including valproate, lamotrigine, and levetiracetam, as monotherapy or polytherapy with different combinations, but still experiencing 3-5 GTCSs each year. At age 25 years, she started to develop myoclonic jerks, which manifested with a brief, shock-like, involuntary movement of the upper limbs, more severe distally and aggravated by motion, and clonazepam was added with significant improvement. One year ago, the patient gradually exhibited unsteadiness, speech disturbance, and memory decline. Neurologic examination revealed mild cerebellar dysarthria, dysmetria performing finger-to-nose test, and positive Romberg sign. Ophthalmoplegia, nystagmus, and saccadic movements were not observed. She had normal muscle strength without rigidity, normal deep tendon reflexes, and a Mini-Mental State Examination score of 20. Brain MRI revealed mild atrophy of the cerebellum and cerebral cortex (figure). Videoelectroencephalography (video-EEG) showed normal background activities and intermittent spikes involving the posterior head region. Photic sensitivity was absent. Considering the progressiveness and the involvement of multiple neurologic systems of this patient, inherited neurodegenerative diseases were suspected. Whole-exome sequencing identified a reported variant c.1550T>G (p.L517W) in the TGM6 gene. Given that epilepsy has not been reported in patients with TGM6 mutations, we further studied ataxia caused by trinucleotide (or pentanucleotide) repeat expansion. Surprisingly, genetic testing using capillary electrophoresis revealed 14/61 CAG repeats in the atrophin-1 (ATN1) gene on chromosome 12p13.31, which is a well-established gene for DRPLA. However, this raises the question whether this patient happened to harbor double mutations, which might have additive effects on the phenotype, or the TGM6 p.L517W variant is not actually pathogenic. 


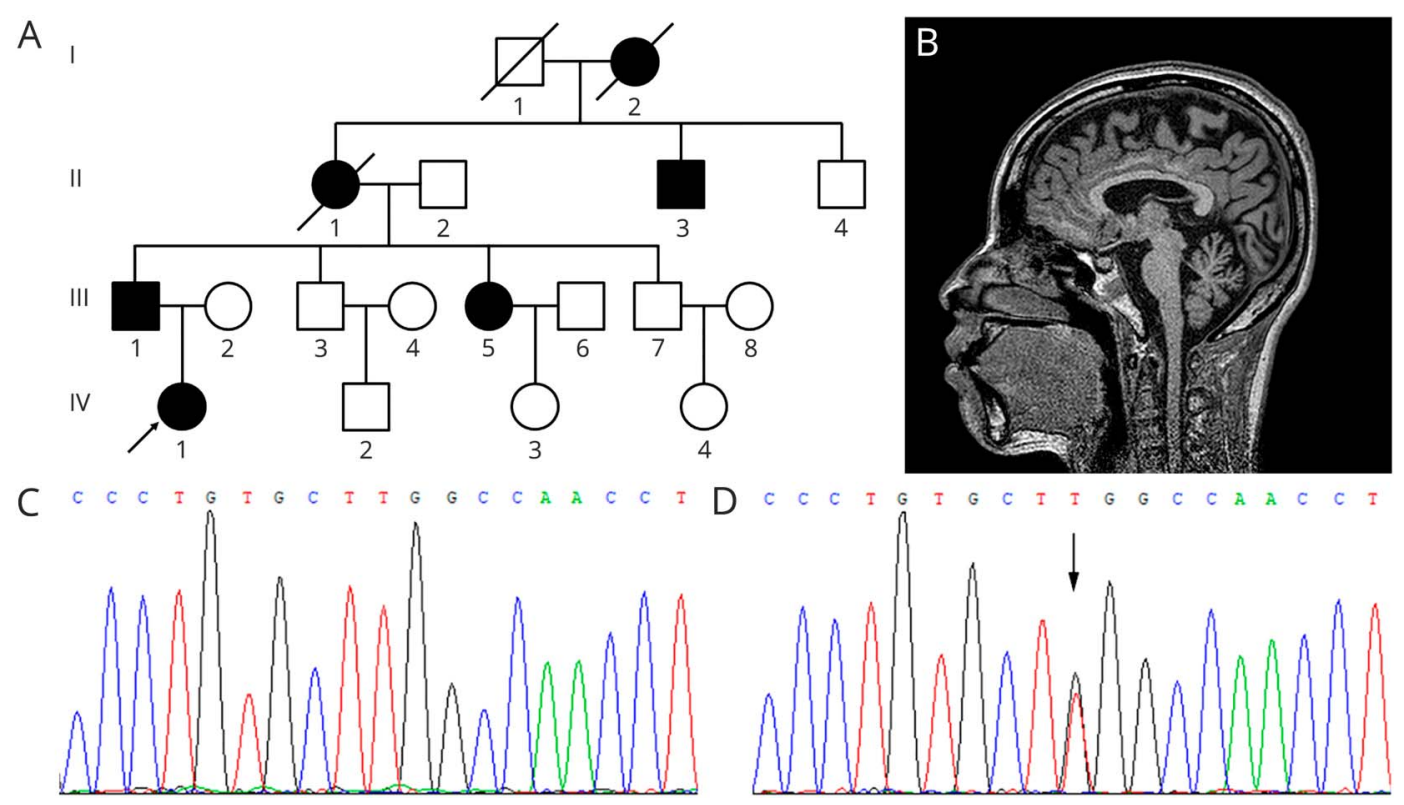

(A) Family pedigree of DRPLA disease. (B) Brain MRI of the proband showing mild cerebellar atrophy. (C) Normal control of the TGM6 gene. (D) The TGM6 variant in the patient. Arrows indicate the variant site. DRPLA = dentatorubral-pallidoluysian atrophy.

We subsequently studied the whole family and found that family members I:2, II:1, II:3, III:1, and III:5 developed cerebellar ataxia and cognitive decline/dementia in their fifties or sixties (table). The TGM6 p.L517W variant was absent in patients III:5 and II:3, but present in unaffected individuals (II: 4, III:3, and III:7). The nonsegregation of the TGM6 variant with phenotype does not support this variant as the diseasecausing gene in this family. On the other hand, the CAG repeat number was expanded in all the patients (II:3, III:1, III:5, and IV:1) and within normal range in all the unaffected family members with available DNA, perfectly cosegregating with disease phenotype. No DNA was available from the deceased patients (I:1, I:2, and II:1). Patient II:1 died of gastric cancer at age 53 years. The presence of the ATN1 variant in her children indicates that patient II: 1 should be a carrier. This observation strongly suggests that the disease is caused by the CAG repeat expansion in ATN1 rather than the p.L517W variant in TMG6.

\section{Discussion}

In the current study, we present a 4-generation pedigree with ataxia and cognitive decline/dementia. One well-established CAG expansion in ATN1 and another reported pathogenic TGM6 p.L517W variant were identified. Cosegregation analysis confirmed the ATN1 mutation as the disease-causing gene, casting doubts on the pathogenicity of the TGM6 p.L517W variant.

ATN1 is a well-established gene for DRPLA, which is a rare, inherited $\mathrm{AD}$ neurodegenerative disorder resulting from an unstable CAG trinucleotide repeat expansion in ATN1. Normally, the CAG tract bears 6-35 repeats, which expands to over 49 in patients with DRPLA. ${ }^{10}$ The clinical features of DRPLA are strikingly heterogeneous, depending on the age at disease onset and the prominent genetic anticipation. ${ }^{11}$ Patients with juvenile-onset (onset before age 20 years) frequently exhibit progressive myoclonic epilepsy, intellectual disabilities, and ataxia. Various forms of seizures are common features in all patients with onset before age 20 years. Patients with onset after age 20 years typically present symptoms including cerebellar ataxia, choreoathetosis, and dementia. Therefore, the clinical manifestations of the proband comply with juvenileonset DRPLA, while the other affected family members also fit well the clinical spectrum of DRPLA.

The identification of TGM6 as a causative gene for SCA35 was first reported in $2010 .{ }^{1}$ The TGM6 p.L517W variant cosegregated with the phenotype in a Chinese 4-generation SCA family. Cosegregation of another variant of TGM6 with the phenotype was also identified in another 2-generation family. More variants in the TGM6 gene were later discovered in patients with ataxia manifestations by other groups, supporting the role of TG6 in ataxia syndrome. ${ }^{2,3,8}$ However, with the wide application of the next-generation sequencing in clinical practice in recent years, increasing genetic results are available, which challenges the previously reported pathogenic variants that have not been extensively validated. Besides, the emerging public database-based variant analysis provides an accessible and efficient approach to test the pathogenicity probability of suspected variants. Recently, in a Chinese exome sequencing cohort, 8 families were found to harbor the reported TGM6 
Table Clinical information and genetic results in the family members

\begin{tabular}{|c|c|c|c|c|c|c|}
\hline $\begin{array}{l}\text { Family } \\
\text { member }\end{array}$ & Sex & Age (y) & $\begin{array}{l}\text { Age at } \\
\text { onset }(y)\end{array}$ & Clinical symptoms & $\begin{array}{l}\text { c. } 1550 T>G \\
\text { variant }\end{array}$ & $\begin{array}{l}\text { ATN1 CAG } \\
\text { repeats }\end{array}$ \\
\hline I:2 & Female & Deceased & NA & Ataxia & I & I \\
\hline II:1 & Female & Deceased & Fifties & Ataxia & I & I \\
\hline $\mathrm{II}: 2$ & Male & 83 & I & None & Negative & $14 / 17$ \\
\hline II:3 & Male & 75 & Sixties & Ataxia/dementia & Negative & $9 / 54$ \\
\hline II:4 & Male & 72 & I & None & Positive & $17 / 18$ \\
\hline III:1 & Male & 56 & 52 & $\begin{array}{l}\text { Ataxia/cognitive } \\
\text { decline }\end{array}$ & Positive & $17 / 55$ \\
\hline III:2 & Female & 50 & I & None & Negative & $14 / 18$ \\
\hline III:3 & Male & 55 & I & None & Negative & $14 / 17$ \\
\hline III:5 & Female & 53 & 48 & $\begin{array}{l}\text { Ataxia/cognitive } \\
\text { decline }\end{array}$ & Negative & $14 / 56$ \\
\hline III:7 & Male & 51 & I & None & Positive & $17 / 17$ \\
\hline IV:1 & Female & 28 & 15 & $\begin{array}{l}\text { Seizure/myoclonus/ } \\
\text { ataxia/cognitive decline }\end{array}$ & Positive & $14 / 61$ \\
\hline
\end{tabular}

Abbreviation: $\mathrm{NA}=$ not available.

variants but share no features of SCA35. They further reviewed the public database genomAD and found that the reported pathogenic variants, including $\mathrm{L} 517 \mathrm{~W}$, are significantly more common in East Asians than in other ethnic groups. Gene constraint metrics showed that both missense and loss-offunction variants in TGM6 are unlikely to be disease causing. Inflation analysis of the reported pathogenic TGM6 variants showed that there is an at least 111-fold inflation over disease prevalence of all $\mathrm{AD}$ SCAs. This level of inflation is far beyond the threshold of 10-fold, which indicates a high chance of misdiagnosis/misclassification of the variant or very low penetrance. They raised the concern that misclassification of benign or low penetrant variants as pathogenic is a significant problem, which would often result in genetic misdiagnosis. ${ }^{12}$ However, this study still fails to reach a definite conclusion regarding the causality between the genotype and phenotype. First, the inability to perform cosegregation analysis in this study cannot rule out the likelihood of incomplete penetrance of the variants. Second, the size of database and the ethnic recruiting bias should be taken into consideration when interpreting the results. Last, the majority of index individuals in their cohort were infants or children, and half of their asymptomatic variant-carrying parents were under middle age. Thus, there exists possibility that they might become symptomatic at older age, given that the mean age at onset for SCA35 was 43.7 years. ${ }^{1}$ Pedigree cosegregation analysis could provide additional evidence on the pathogenicity of the variants, especially that lack of segregation of a variant is strong evidence against pathogenicity. Therefore, the pedigree we report here is of special value. The nonsegregation of the variant in this pedigree provides direct and compelling evidence that the TMG6 p.L517W is not pathogenic.

A few functional studies of the TMG6 variants indicate a biologically possible link with neurodegeneration. The subcellular distribution, expression, and in vitro activity of the 2 variants of TGM6 (D327G and L517W) have been investigated. In 1 study, it was found that neither of the mutants changed the subcellular localization of TG6, but exhibited decreased transglutaminase activity and exerted the cells more vulnerable to staurosporine-induced apoptosis. ${ }^{13}$ On the other hand, another study found that 5 previously reported TGM6 mutations, including L517W, were associated with nuclear depletion of TG6 and loss of the transglutaminase activity, and thus leading to the activation of the unfolded protein response and neuronal death. ${ }^{8}$ These studies showed an increased vulnerability of cells transfected with TGM6 variants, suggesting a role of TG6 in neuronal viability. However, variants associated biological function changes might not be responsible for the clinical manifestations observed in patients, which are also commonly seen in risk genes. Even healthy individuals carry many rare protein-disrupting variants. ${ }^{14}$ Therefore, further functional studies that can replicate the disease-relevant phenotypes are needed to establish the causal relationship between TGM6 variants and the disease phenotype.

We report a pedigree with ataxia, in which a well-established ATN1 mutation and a TGM6 variant were identified. Nonsegregation of the TGM6 L517W variant with disease phenotype indicates that this variant is not disease causing. We do 
not rule out the possibility that certain genuine pathogenic TGM6 variants might exist.

\section{Acknowledgment}

The authors thank the patients and their families for participating in this study.

\section{Study funding}

This study was supported by the National Key R\&D Program of China (2017YFC0907700), National Natural Science Foundation of China (81870826), and Zhejiang Provincial Natural Science Foundation of China (LY19H180006, LY18H090004).

\section{Disclosure}

Y. Chen, D. Wu, B. Luo, G. Zhao, and K. Wang report no disclosures. Go to Neurology.org/NG for full disclosures.

\section{Publication history}

Received by Neurology: Genetics November 16, 2019. Accepted in final form March 13, 2020.

\section{Appendix Authors}

\begin{tabular}{lll}
\hline Name & Location & Contributions \\
\hline $\begin{array}{l}\text { Yanxing } \\
\text { Chen, MD, } \\
\text { PhD }\end{array}$ & $\begin{array}{l}\text { Department of Neurology, } \\
\text { the Second Affiliated } \\
\text { Hospital, School of } \\
\text { Medicine, Zhejiang } \\
\text { University, Hangzhou, } \\
\text { China }\end{array}$ & $\begin{array}{l}\text { Drafted the manuscript; } \\
\text { major role in acquisition } \\
\text { and interpretation of data; } \\
\text { and critical review }\end{array}$ \\
\hline $\begin{array}{l}\text { Dengchang } \\
\text { PhD MD, }\end{array}$ & $\begin{array}{l}\text { Department of Neurology, } \\
\text { the First Affiliated Hospital, }\end{array}$ & $\begin{array}{l}\text { Acquisition and } \\
\text { interpretation of data and } \\
\text { critical review }\end{array}$ \\
\hline $\begin{array}{l}\text { School of Medicine, } \\
\text { Bangzhou, China }\end{array}$ & \\
$\begin{array}{l}\text { Luo, MD, } \\
\text { PhD }\end{array}$ & $\begin{array}{l}\text { Department of Neurology, } \\
\text { the First Affiliated Hospital, }\end{array}$ & $\begin{array}{l}\text { Acquisition and } \\
\text { interpretation of data and } \\
\text { critical review }\end{array}$ \\
& $\begin{array}{l}\text { School of Medicine, } \\
\text { Hangzhou, China }\end{array}$ & \\
\hline
\end{tabular}

Appendix (continued)

\begin{tabular}{lll}
\hline Name & Location & Contributions \\
\hline $\begin{array}{l}\text { Guohua } \\
\text { Zhao, MD, } \\
\text { PhD }\end{array}$ & $\begin{array}{l}\text { Department of Neurology, } \\
\text { the Second Affiliated } \\
\text { Hospital, School of } \\
\text { Medicine, Zhejiang } \\
\text { University, Hangzhou, } \\
\text { China }\end{array}$ & $\begin{array}{l}\text { Designed and } \\
\text { conceptualized the study; } \\
\text { major role in acquisition } \\
\text { and interpretation of data; } \\
\text { and critical review }\end{array}$ \\
\hline Kang Wang, \\
MD, PhD & $\begin{array}{l}\text { Department of Neurology, } \\
\text { the First Affiliated Hospital, } \\
\text { School of Medicine, } \\
\text { Hangzhou, China }\end{array}$ & $\begin{array}{l}\text { Designed and } \\
\text { conceptualized the study; } \\
\text { major role in acquisition } \\
\text { and interpretation of data; } \\
\text { and critical review }\end{array}$ \\
\hline
\end{tabular}

\section{References}

1. Wang JL, Yang X, Xia K, et al. TGM6 identified as a novel causative gene of spinocerebellar ataxias using exome sequencing. Brain 2010;133:3510-3518.

2. Li M, Pang SY, Song Y, Kung MH, Ho SL, Sham PC. Whole exome sequencing identifies a novel mutation in the transglutaminase 6 gene for spinocerebellar ataxia in a Chinese family. Clin Genet 2013;83:269-273.

3. Pan LL, Huang YM, Wang M, et al. Positional cloning and next-generation sequencing identified a TGM6 mutation in a large Chinese pedigree with acute myeloid leukaemia. Eur J Hum Genet 2015;23:218-223.

4. Guo YC, Lin JJ, Liao YC, Tsai PC, Lee YC, Soong BW. Spinocerebellar ataxia 35: novel mutations in TGM6 with clinical and genetic characterization. Neurology 2014; 83:1554-1561.

5. Fasano A, Hodaie M, Munhoz RP, Rohani M. SCA 35 presenting as isolated treatmentresistant dystonic hand tremor. Parkinsonism Relat Disord 2017;37:118-119.

6. Yang ZH, Shi MM, Liu YT, et al. TGM6 gene mutations in undiagnosed cerebellar ataxia patients. Parkinsonism Relat Disord 2018;46:84-86.

7. Choi KD, Kim JS, Kim HJ, et al. Genetic variants associated with episodic ataxia in Korea. Sci Rep 2017;7:13855.

8. Tripathy D, Vignoli B, Ramesh N, et al. Mutations in TGM6 induce the unfolded protein response in SCA35. Hum Mol Genet 2017;26:3749-3762.

9. Lin CC, Gan SR, Gupta D, Alaedini A, Green PH, Kuo SH. Hispanic spinocerebellar ataxia type 35 (SCA35) with a novel frameshift mutation. Cerebellum 2019;18:291-294.

10. Wardle M, Morris HR, Robertson NP. Clinical and genetic characteristics of nonAsian dentatorubral-pallidoluysian atrophy: a systematic review. Mov Disord 2009; 24:1636-1640.

11. Tsuji S. Dentatorubral-pallidoluysian atrophy. Handb Clin Neurol 2012;103: 587-594.

12. Fung JLF, Tsang MHY, Leung GKC, et al. A significant inflation in TGM6 genetic risk casts doubt in its causation in spinocerebellar ataxia type 35. Parkinsonism Relat Disord 2019;63:42-45.

13. Guan WJ, Wang JL, Liu YT, et al. Spinocerebellar ataxia type 35 (SCA35)-associated transglutaminase 6 mutants sensitize cells to apoptosis. Biochem Biophys Res Commun 2013;430:780-786.

14. Tennessen JA, Bigham AW, O'Connor TD, et al. Evolution and functional impact of rare coding variation from deep sequencing of human exomes. Science 2012;337:64-69. 


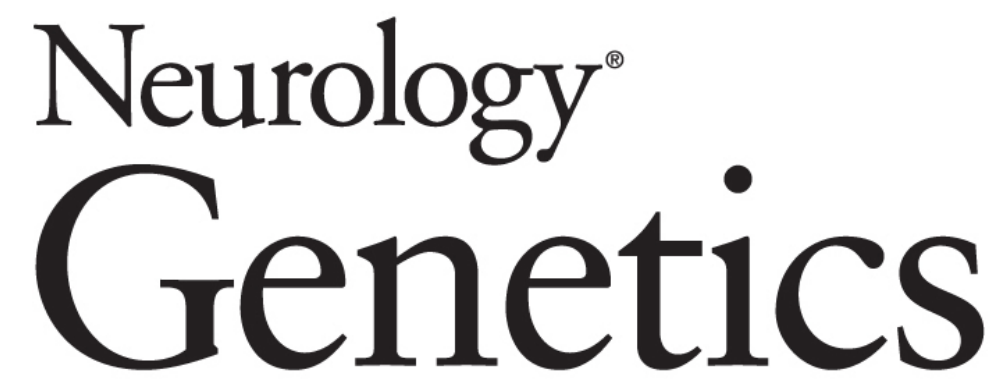

TGM6 $\mathrm{L} 517 \mathrm{~W}$ is not a pathogenic variant for spinocerebellar ataxia type 35

Yanxing Chen, Dengchang Wu, Benyan Luo, et al.

Neurol Genet 2020;6;

DOI 10.1212/NXG.0000000000000424

This information is current as of April 22, 2020

Neurol Genet is an official journal of the American Academy of Neurology. Published since April 2015, it is an open-access, online-only, continuous publication journal. Copyright Copyright (C) 2020 The Author(s). Published by Wolters Kluwer Health, Inc. on behalf of the American Academy of Neurology.. All rights reserved. Online ISSN: 2376-7839.

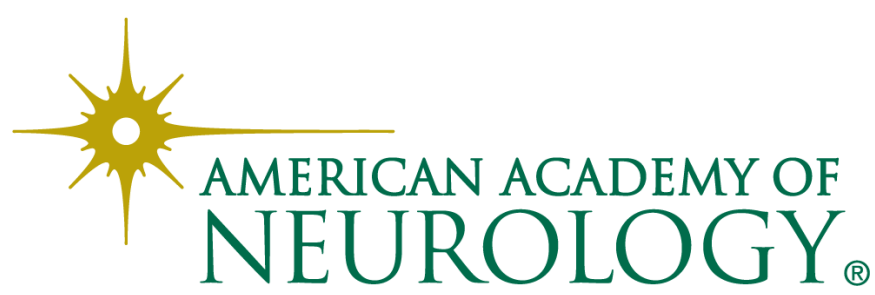




\section{Updated Information \& Services}

References

Subspecialty Collections

Permissions \& Licensing

Reprints including high resolution figures, can be found at: http://ng.neurology.org/content/6/3/e424.full.html

This article cites 14 articles, 1 of which you can access for free at: http://ng.neurology.org/content/6/3/e424.full.html\#\#ref-list-1

This article, along with others on similar topics, appears in the following collection(s):

Dementia aphasia

http://ng.neurology.org//cgi/collection/dementia_aphasia

Gait disorders/ataxia

http://ng.neurology.org//cgi/collection/gait_disorders_ataxia

Myoclonus; see Movement Disorders/myoclonus

http://ng.neurology.org//cgi/collection/myoclonus_see_movement_diso rders-myoclonus

Spinocerebellar ataxia

http://ng.neurology.org//cgi/collection/spinocerebellar_ataxia

Trinucleotide repeat diseases

http://ng.neurology.org//cgi/collection/trinucleotide_repeat_diseases

Information about reproducing this article in parts (figures,tables) or in its entirety can be found online at:

http://ng.neurology.org/misc/about.xhtml\#permissions

Information about ordering reprints can be found online:

http://ng.neurology.org/misc/addir.xhtml\#reprintsus

Neurol Genet is an official journal of the American Academy of Neurology. Published since April 2015, it is an open-access, online-only, continuous publication journal. Copyright Copyright $\odot 2020$ The Author(s). Published by Wolters Kluwer Health, Inc. on behalf of the American Academy of Neurology.. All rights reserved. Online ISSN: 2376-7839.

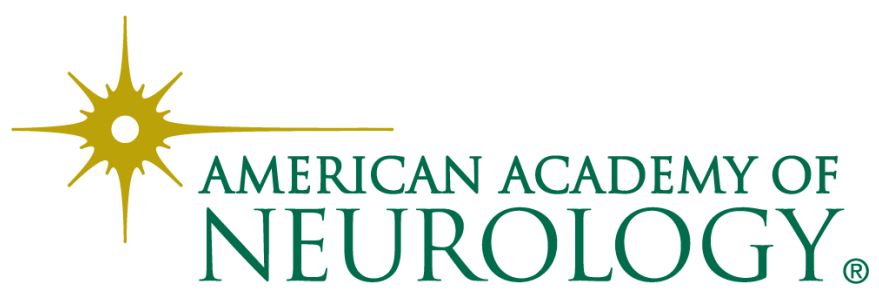

